\title{
Efficacy of increased-dose erlotinib for central nervous system metastases in non-small cell lung cancer patients with epidermal growth factor receptor mutation
}

\author{
Yosuke Togashi $\cdot$ Katsuhiro Masago $\cdot$ Masahide Fukudo $\cdot$ Yasuhiro Tsuchido • \\ Chiyuki Okuda $\cdot$ Young Hak Kim · Yasuaki Ikemi · Yuichi Sakamori • \\ Tadashi Mio $\cdot$ Toshiya Katsura $\cdot$ Michiaki Mishima
}

Received: 20 April 2011 / Accepted: 1 June 2011/Published online: 17 June 2011

(C) The Author(s) 2011. This article is published with open access at Springerlink.com

\begin{abstract}
Purpose Recent reports indicate that refractory central nervous system (CNS) metastases of non-small cell lung cancer (NSCLC) are improved by high-dose gefitinib or erlotinib administration. We describe a Japanese woman with NSCLC and CNS metastases who was resistant to $75 \mathrm{mg}$ daily erlotinib, but the metastases were improved by $150 \mathrm{mg}$ daily erlotinib. We investigated the plasma and CSF concentrations of erlotinib at each dose as well as the correlation between the plasma and CSF concentrations of erlotinib.

Methods Including this patient, we administered $150 \mathrm{mg}$ erlotinib daily to nine NSCLC patients with CNS metastases and measured the plasma and CSF concentrations just before administration on day 8 . The concentrations were determined using high-performance liquid chromatography with ultraviolet detection.

Results The plasma and CSF concentrations of erlotinib at a dose of $75 \mathrm{mg}$ were 433 and $14 \mathrm{nM}$, respectively. The plasma and CSF concentrations of erlotinib at a dose of $150 \mathrm{mg}$ were increased to 1,117 and $44 \mathrm{nM}$, respectively. The mean \pm standard deviation of CSF concentrations and penetration rates were $106 \pm 59 \mathrm{nM}$ and $4.5 \pm 1.5 \%$, respectively. There was a good correlation $\left(R^{2}=0.84\right)$ between plasma and CSF concentrations $(P=0.0005)$.
\end{abstract}

Y. Togashi $(\bowtie) \cdot$ K. Masago · Y. Tsuchido · C. Okuda

Y. H. Kim - Y. Sakamori - T. Mio - M. Mishima

Department of Respiratory Medicine, Graduate School

of Medicine, Kyoto University, 54 Shogoin-Kawaracho,

Sakyo-ku, Kyoto 606-8507, Japan

e-mail: ytogashi@kuhp.kyoto-u.ac.jp

M. Fukudo - Y. Ikemi - T. Katsura

Department of Pharmacy, Graduate School of Medicine,

Kyoto University, 54 Shogoin-Kawaracho, Sakyo-ku,

Kyoto 606-8507, Japan
Conclusions This study indicates that CSF concentrations of erlotinib depend on its plasma concentration. As seen in this patient, high CSF concentrations of erlotinib can be achieved by high-dose administration, and this finding suggests the efficacy of high-dose administration, especially to refractory CNS metastases of NSCLC patients.

Keywords Non-small cell lung cancer · Epidermal growth factor receptor - Tyrosine kinase inhibitor . Erlotinib - Central nervous system metastasis .

Cerebrospinal fluid

\section{Introduction}

Patients with non-small cell lung cancer (NSCLC) who have somatic activating mutations of the epidermal growth factor receptor (EGFR) gene (EGFR mutations) generally respond to EGFR-tyrosine kinase inhibitors (EGFR-TKIs, e.g., gefitinib and erlotinib) $[1,2]$. Nevertheless, the majority of these patients experience eventual disease progression, despite an initial dramatic response to treatment. The central nervous system (CNS) is a common site of recurrence, which is thought to be due to penetration of the agents into the CNS [3, 4]. A previous report described refractory CNS metastases of NSCLC that were improved by high-dose gefitinib [5]. Several cases in which CNS metastases resistant to gefitinib were improved by erlotinib have been also reported [6]. In addition, in several articles, intermittent, high-dose erlotinib improved CNS metastases that were resistant to continuous, normal-dose erlotinib [79]. These challenges are based on the hypothesis that high cerebrospinal fluid (CSF) concentrations may be achieved by high-dose administration of EGFR-TKIs, with higher CSF concentrations achieved by erlotinib compared with 
gefitinib. We previously reported the CSF concentrations of erlotinib and its penetration rates in four NSCLC patients with CNS metastases [10]. In this article, we describe a Japanese woman with NSCLC and EGFR mutation having CNS metastases that are resistant to $75 \mathrm{mg}$ daily erlotinib. The metastases were subsequently improved by $150 \mathrm{mg}$ daily erlotinib. We investigated the plasma and CSF concentrations of erlotinib at each dose. Furthermore, including previous data, we investigated the correlation between plasma and CSF concentrations.

\section{Patients and methods}

\section{Patients}

A 66-year-old Japanese woman was diagnosed with advanced lung adenocarcinoma and EGFR mutation
(L858R) 3 years prior. Erlotinib had been administered as fourth line of treatment. Before the initiation of erlotinib, the patient had no CNS metastases. Although partial response (PR) was achieved, the erlotinib dose was reduced from 150 to $75 \mathrm{mg}$ daily due to grade 3 fatigue. After progression-free survival (PFS) of 12 months, the patient experienced recurrent CNS metastases. The plasma and CSF concentrations of erlotinib just before administration of the 75-mg dose were 433 and $14 \mathrm{nM}$, respectively. The patient received whole-brain radiotherapy (WBRT), but the CNS metastases did not improve (Fig. 1a). The dose was subsequently increased to $150 \mathrm{mg}$ daily; the plasma and CSF concentrations just before administration of erlotinib on day 8 erlotinib were 1,117 and $44 \mathrm{nM}$, respectively. Four weeks after the initiation of $150 \mathrm{mg}$ administration of erlotinib, CNS metastases improved (Fig. 1b).

We previously reported the plasma and CSF concentrations of four NSCLC patients with CNS metastases
Fig. 1 Brain magnetic resonance imaging (MRI) in the 66-year-old Japanese female patient. a Brain MRI after whole-brain radiotherapy demonstrated stable brain metastases (arrowheads). At this point, $75 \mathrm{mg}$ daily erlotinib was administered. b Four weeks after initiation of $150 \mathrm{mg}$ daily erlotinib, the metastases were improved (arrowheads)
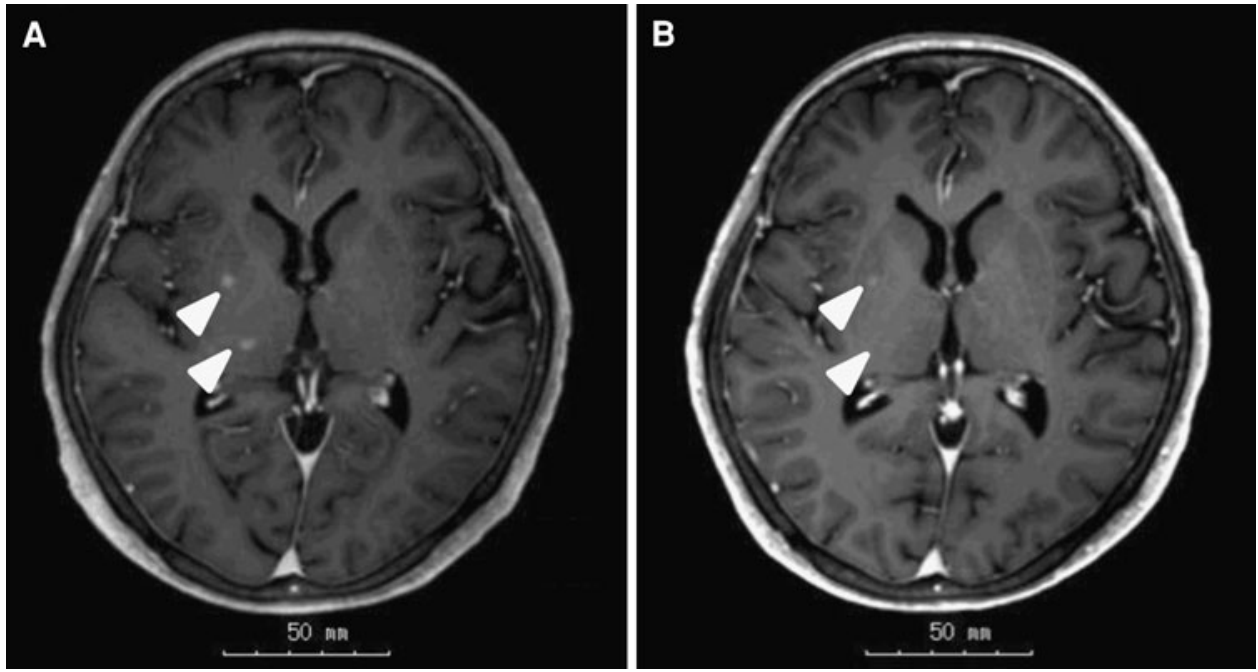

Table 1 Patient characteristics

\begin{tabular}{|c|c|c|c|c|c|c|c|c|c|}
\hline Cases & Age (yr) & Sex & PS & Histology & $E G F R$ gene & $\begin{array}{l}\text { Smoking } \\
\text { status }\end{array}$ & $\begin{array}{l}\text { Previous chemotherapy } \\
\text { regimen }\end{array}$ & $\begin{array}{l}\text { Previous gefitinib } \\
\text { (length of PFS) }\end{array}$ & $\begin{array}{l}\text { Previous } \\
\text { WBRT }\end{array}$ \\
\hline 1 & 59 & $\mathrm{~F}$ & 3 & Ad & $\mathrm{NE}$ & Never & 3 & Yes (10 months) & Yes \\
\hline 2 & 82 & $\mathrm{~F}$ & 4 & Ad & Wild type & Never & 0 & No & No \\
\hline 3 & 70 & $\mathrm{~F}$ & 3 & Ad & Wild type & Never & 1 & No & Yes \\
\hline 4 & 86 & $\mathrm{~F}$ & 3 & Ad & Ex 21; L858R & Never & 1 & Yes ( 7 months) & No \\
\hline 5 & 67 & $\mathrm{~F}$ & 1 & Ad & Ex 21; L858R & Never & 1 & No & No \\
\hline 6 & 72 & $\mathrm{M}$ & 0 & Ad & Ex 21; L858R & Former & 1 & No & No \\
\hline 7 & 81 & M & 1 & Ad & Ex 19 deletion & Former & 1 & Yes (46 months) & Yes \\
\hline 8 & 85 & $\mathrm{~F}$ & 2 & Ad & Ex 21; L858R & Never & 1 & No & Yes \\
\hline $\mathrm{a}$ & 66 & $\mathrm{~F}$ & 1 & Ad & Ex 21; L858R & Never & 3 & No & Yes \\
\hline
\end{tabular}

$P S$ performance status, $E G F R$ epidermal growth factor receptor, $P F S$ progression-free survival, $W B R T$ whole-brain radiotherapy, $F$ female, $M$ male, Ad adenocarcinoma, NE not evaluated, Never never-smoker, Former former-smoker

a A 66-year-old Japanese female patient in this study 


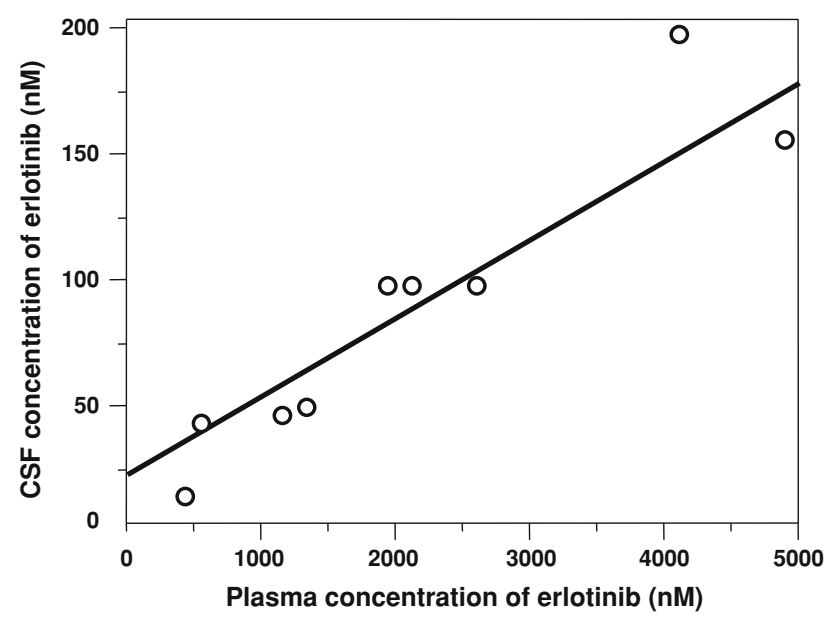

Fig. 2 Correlation between plasma concentrations and cerebrospinal fluid (CSF) concentrations of erlotinib. A good correlation $\left(R^{2}=0.84\right)$ was demonstrated $(P=0.0005)$

(cases 1-4) [10]. In addition to these patients, we investigated the plasma and CSF concentrations of four other NSCLC patients with CNS metastases (cases 5-8) (Table 1).

\section{Methods}

Blood and CSF samples were obtained just before the administration of $150 \mathrm{mg}$ erlotinib on day 8 when steadystate plasma concentrations of erlotinib were assumed to be achieved. Plasma and CSF concentrations of erlotinib were determined using high-performance liquid chromatography with ultraviolet detection as previously reported [11].
Before the collection of samples and analysis, we obtained written informed consent from all patients.

Statistical analysis

Linear regression was performed on the data in Fig. 2 by fitting a straight line. The $R^{2}$ value was used to measure the strength of the relationship between the plasma and CSF concentrations of erlotinib. The $150-\mathrm{mg}$ daily erlotinib data from this 66-year-old Japanese female patient were analyzed, and the 75-mg daily erlotinib data were excluded. Linear regression analysis, performed using JMP 8 software (SAS Institute, Cary, NC, USA), was two-tailed, and $P$ values less than 0.05 were considered statistically significant.

\section{Results}

The clinical characteristics of all patients $(n=9)$ are summarized in Table 1. In CNS lesions, 7 of the 9 patients achieved PR (78\%) and 5 of the 6 patients with EGFR mutations achieved PR (83\%). Gefitinib was administered to three patients prior to erlotinib therapy; these patients achieved PR but had CNS recurrence after a long PFS of more than 6 months. Two of these three patients achieved PR after erlotinib therapy in spite of gefitinib resistance.

The plasma and CSF concentrations are summarized in Table 2. The mean \pm standard deviation (SD) of CSF concentrations and penetration rates were $106 \pm 59 \mathrm{nM}$ and $4.5 \pm 1.5 \%$, respectively. As seen in Fig. 2, there was a good correlation $\left(R^{2}=0.84\right)$ between plasma and CSF concentrations $(P=0.0005)$.

Table 2 Plasma and cerebrospinal fluid concentrations of erlotinib, and central nervous system metastases response

\begin{tabular}{|c|c|c|c|c|}
\hline Case & $\begin{array}{l}\text { Plasma } \\
\text { concentration }(\mathrm{nM})\end{array}$ & $\begin{array}{l}\text { CSF } \\
\text { concentration }(\mathrm{nM})\end{array}$ & $\begin{array}{l}\text { Penetration } \\
\text { rate }(\%)\end{array}$ & CNS response $^{\mathrm{a}}$ \\
\hline 1 & 2,082 & 98 & 4.7 & Partial response \\
\hline 2 & 4,059 & 202 & 5.0 & Stable disease \\
\hline 3 & 4,922 & 156 & 3.2 & Partial response \\
\hline 4 & 544 & 42 & 7.7 & Stable disease \\
\hline 5 & 2,575 & 98 & 3.8 & Partial response \\
\hline 6 & 1,314 & 47 & 3.5 & Partial response \\
\hline 7 & 1,886 & 98 & 5.2 & Partial response \\
\hline 8 & 5,376 & 172 & 3.2 & Partial response \\
\hline$(75 \mathrm{mg} \text { erlotinib })^{\mathrm{b}}$ & 433 & 14 & 3.3 & Progressive disease \\
\hline$(150 \mathrm{mg} \text { erlotinib })^{\mathrm{b}}$ & 1,117 & 44 & 3.9 & Partial response \\
\hline Mean $\pm \operatorname{SD}^{c}$ & $2,653 \pm 1,734$ & $106 \pm 59$ & $4.5 \pm 1.5$ & \\
\hline
\end{tabular}

$C S F$ cerebrospinal fluid, $C N S$ central nervous system, $S D$ standard deviation

${ }^{a}$ Responses were assessed by magnetic resonance imaging with use of the Response Evaluation Criteria in Solid Tumor version 1.1

b A 66-year-old Japanese female patient in this study

${ }^{c}$ We analyzed the mean \pm SD from all data except for the data from the 66-year-old Japanese female patient at a dose of $75 \mathrm{mg}$ erlotinib 


\section{Discussion}

This study demonstrated that there is a good correlation $\left(R^{2}=0.84\right)$ between plasma and CSF concentrations of erlotinib $(P=0.0005)$, which indicates that high CSF concentrations can be achieved by high plasma concentrations. That is, high CSF concentrations can be achieved by high-dose erlotinib administration. CNS metastases of the 66-year-old Japanese female patient responded to $150 \mathrm{mg}$ daily erlotinib despite resistance to $75 \mathrm{mg}$ daily erlotinib, likely because of higher CSF concentrations. There are several reports based on the hypothesis that high CSF concentrations may be achieved by high-dose erlotinib administration [5-9], and our study supports this hypothesis.

The mean $\pm \mathrm{SD}$ of $\mathrm{CSF}$ penetration rates were $4.5 \pm 1.5 \%$, and this result was similar to that of recent another study [12]. However, the rates of our study were ranged from 3.2 to $7.7 \%$ and those of another study ranged from 2.5 to $13.3 \%$, which indicates that there seem to be difference in the penetration rate between individuals. Recently, it has been reported that some transporters restrict brain penetration of erlotinib [13, 14]. Polymorphisms of these transporters can be associated with this individual difference in the penetration rate.

Since systemic chemotherapy is thought to play a limited role in CNS metastases because of the belief that the brain is a pharmacological sanctuary, patients with NSCLC who showed initial good responses to EGFR-TKIs often had recurrent CNS metastases. Considering CSF concentrations, high-dose EGFR-TKIs can be effective for such refractory metastases. Furthermore, the association between CNS responses/recurrence and CSF concentrations should be investigated in the future.

Conflicts of interest We declare that we have no potential conflict of interest related to this article.

Open Access This article is distributed under the terms of the Creative Commons Attribution Noncommercial License which permits any noncommercial use, distribution, and reproduction in any medium, provided the original author(s) and source are credited.

\section{References}

1. Paez JG, Jänne PA, Lee JC, Tracy S, Greulich H, Gabriel S, Herman P, Kaye FJ, Lindeman N, Boggon TJ, Naoki K, Sasaki H, Fujii Y, Eck MJ, Sellers WR, Johnson BE, Meyerson M (2004) EGFR mutations in lung cancer: correlation with clinical response to gefitinib therapy. Science 304:1497-1500
2. Lynch TJ, Bell DW, Sordella R, Gurubhagavatula S, Okimoto RA, Brannigan BW, Harris PL, Haserlat SM, Supko JG, Haluska FG, Louis DN, Christiani DC, Settleman J, Haber DA (2004) Activating mutations in the epidermal growth factor receptor underlying responsiveness of non-small-cell lung cancer to gefitinib. N Engl J Med 350:2129-2139

3. Omuro AM, Kris MG, Miller VA, Franceschi E, Shah N, Milton DT, Abrey LE (2005) High incidence of disease recurrence in the brain and leptomeninges in patients with nonsmall cell lung carcinoma after response to gefitinib. Cancer 103:2344-2348

4. Lee YJ, Choi HJ, Kim SK, Chang J, Moon JW, Park IK, Kim JH, Cho BC (2010) Frequent central nervous system failure after clinical benefit with epidermal growth factor receptor tyrosine kinase inhibitors in Korean patients with nonsmall-cell lung cancer. Cancer 116:1336-1343

5. Jackman DM, Holmes AJ, Lindeman N, Wen PY, Kesari S, Borras AM, Bailey C, de Jong F, Jänne PA, Johnson BE (2006) Response and resistance in a non-small-cell lung cancer patient with an epidermal growth factor receptor mutation and leptomeningeal metastases treated with high-dose gefitinib. J Clin Oncol 24:4517-4520

6. Katayama T, Shimizu J, Suda K, Onozato R, Fukui T, Ito S, Hatooka S, Sueda T, Hida T, Yatabe Y, Mitsudomi T (2009) Efficacy of erlotinib for brain and leptomeningeal metastases in patients with lung adenocarcinoma who showed initial good response to gefitinib. J Thorac Oncol 4:1415-1419

7. Dhruva N, Socinski MA (2009) Carcinomatous meningitis in non-small-cell lung cancer: response to high-dose erlotinib. J Clin Oncol 27:31-32

8. Clarke JL, Pao W, Wu N, Miller VA, Lassman AB (2010) High dose weekly erlotinib achieves therapeutic concentrations in CSF and is effective in leptomeningeal metastases from epidermal growth factor receptor mutant lung cancer. J Neurooncol 99:283-286

9. Hata A, Kaji R, Fujita S, Katakami N (2011) High-dose erlotinib for refractory brain metastases in a patient with relapsed nonsmall cell lung cancer. J Thorac Oncol 6:653-654

10. Togashi Y, Masago K, Fukudo M, Terada T, Fujita S, Irisa K, Sakamori Y, Kim YH, Mio T, Inui K, Mishima M (2010) Cerebrospinal fluid concentration of erlotinib and its active metabolite OSI-420 in patients with central nervous system metastases of non-small cell lung cancer. J Thorac Oncol 5:950-955

11. Zhang W, Siu LL, Moore MJ, Chen EX (2005) Simultaneous determination of OSI-774 and its major metabolite OSI-420 in human plasma by using HPLC with UV detection. J Chromatogr B Analyt Technol Biomed Life Sci 814:143-147

12. Masuda T, Hattori N, Hamada A, Iwamoto H, Ohshimo S, Kanehara M, Ishikawa N, Fujitaka K, Haruta Y, Murai H, Kohno N (2011) Erlotinib efficacy and cerebrospinal fluid concentration in patients with lung adenocarcinoma developing leptomeningeal metastases during gefitinib therapy. Cancer Chemother Pharmacol 67:1465-1469

13. Elmeliegy MA, Carcaboso AM, Tagen M, Bai F, Stewart CF (2011) Role of ATP-binding cassette and solute carrier transporters in erlotinib CNS penetration and intracellular accumulation. Clin Cancer Res 17:89-99

14. de Vries NA, Buckle T, Zhao J, Beijnen JH, Schellens JH, van Tellingen $O$ (2010) Restricted brain penetration of the tyrosine kinase inhibitor erlotinib due to the drug transporters P-gp and BCRP. Invest New Drugs [Epub ahead of print] 